\title{
DEMOKRACIJA, KAPITALIZAM, SOCIJALNA PRAVEDNOST Društvene i političke perspektive danas
}

\author{
Heinz Sünker \\ Fakultät Human- und Sozialwissenschaften \\ Bergische Universität Wuppertal \\ E-mail: suenker@uni-wuppertal.de
}

DOI: 10.20901/an.13.02

Pregledni članak

Primljeno: prosinac 2016.

\author{
Prometej 70 \\ Samo ponekad \\ Kad toplana štrajka \\ Ili ugljen \\ Ne stigne na vrijeme \\ Čovjeka prikovanog \\ Za vlastitu kuću \\ Malo spopadne svagdašnja zlovolja. \\ Kurt Bartsch, Stroj za smijeh
}

\begin{abstract}
Sažetak Autor raspravlja o problemu socijalne pravednosti, stavljajući u radu naglasak na kompleksan odnos između demokracije, kapitalizma i pravednosti. Glavna ideja koja se razmatra u članku je da je kod svjesne društveno-političke analize koja pitanja načina života i kvalitete života povezuje s klasnouvjetovanim strukturnim pitanjima, uvijek riječ o dilemi demokracija ili kapitalizam. Autor pruža pregled suvremenih rasprava vezanih uz ovu dilemu.
\end{abstract}

Ključne riječi socijalna pravednost, kapitalizam, demokracija

U vremenu koje karakteriziraju monopolistički kapitalizam u obličju neoliberalno ${ }^{1}$ osmišljenog kazino-kapitaliz-

1 Za povijest onoga što se u cjelokupnom kapitalističkom svjetskom sustavu probilo ili se trebalo probiti kao neoliberalizam, za posljedice po socijalne strukture i konkretne uvjete života klasa i pojedinaca vidi temeljne analize Todda (1999), Dixona (2000), Cunninghama (2014), Mirowskog (2014) i Hana (2015). Sve ove studije pokazuju koliko je ma i njegovi financijsko-kapitalistički ekscesi te strukturalna društvena rasci-

Bourdieu imao pravo sa svojom prosudbom 'uspona' neoliberalizma: “Iz razloga koji su nedvojbeno do mene te prvenstveno do trenutačnog stanja svijeta, došao sam do uvjerenja da oni kojima je suđeno svoj život posvetiti istraživanju socijalnoga svijeta, ne mogu ostati neutralni ili indiferentni spram borbi u kojima se odlučuje o budućnosti 
jepljenost na "bogate"2 i "siromašne", kakva je, konačno, u tim razmjerima

ovoga svijeta. Te su borbe najvećim dijelom sukobljavanja u kojima vladajući mogu računati na nebrojene ortake koji se pojavljuju spontano ili su plaćeni. Sjetimo se samo profesionalnih lobista koji se broje u tisućama i koji trčkaraju briselskim hodnicima Europske komisije, Europskoga vijeća ili parlamenta. Ta neoliberalna Vulgata, ekonomsko-politička ortodoksija koja je tako univerzalno provedena i tako jednodušno prihvaćena te se svaka diskusija i svako propitkivanje čini isključenim, ni u kom slučaju nije proizišla iz spontane samokreacije, upravo suprotno, ona je rezultat silnog uloženog rada koji je udružen i organiziran u pravim pravcatim proizvodnim, distribucijskim i intervencijskim poduzećima. Tako je, primjerice, Američka gospodarska komora (AmCham) samo 1998. godine objavila deset knjiga i više od šezdeset izvješća te je sudjelovala na otprilike 350 susreta s Europskom komisijom i Europskim parlamentom... Protiv ovih snaga koje počivaju na udruživanju i mobiliziranju kulturnog kapitala djelotvorno se može nastupiti jedino pomoću prosvjednog pokreta koji se oslanja na sličnu mobilizaciju, ali se ravna prema posve drugim ciljevima" (Bourdieu, 2001a: 7).

2 Protiv ideoloških stajališta poput onoga jednoga Tonya Blaira koji kritičarima bogatih predbacuje "zavist", A. Sayer u svojoj društveno-analitički akcentuiranoj studiji "Why we can't afford the rich" navodi: "Glavni prigovor je da je uloga bogatih u izvlačenju, a ne stvaranju bogatstva... ovo nije studija o politici zavisti... već o politici nepravednosti. Ne radi se o tome da zavidim bogatima, dapače smatram takvu zavist potpuno promašenu. Zamjeram sustavu koji dopušta bogatima da izvlače bogatstvo koje proizvode drugi i dominiraju društvom u svrhu svojih interesa. Ovo je, štoviše, ne samo nepravedno već duboko disfunkcionalno i neefikasno" (2016: 2). Na osnovnu misao njemačkog problema raspodjele upozorava se u djelu pod naslovom "Privatno bogatstvo plaćeno javnim i privatnim siromaštvom?” (Schäfer, 2000).

3 U jednoj se frakciji kršćanske ideologije kao interpretacija Amosa (vidi: Fleischer, 1989) doživljena prije sto godina, dakle jedna ekstremna "socijalna nejednakost", gotovo da je samo po sebi razumljivo da mnogi govore o "socijalnoj pravdi". Govore u društvenopolitičkim raspravama na pozitivan i negativan način, a često i da bi skrenuli pozornost $s$ temeljnih pitanja koja se tiču demokracije i kapitalizma.

S obzirom na tu konjunkturu - prije svega u slučaju onih koji su za tu situaciju odgovorni kao političari zbog, između ostalog, permanentnih snižavanja poreza za različite frakcije kapitala - kod mnogih stajališta unutar društvene i socijalne politike prvenstveno valja ukazati na to da je pozivanje na "socijalnu prav-

i njegovih nasljednika, dakle drugih sociorevolucionarnih proroka Staroga zavjeta, sustavno, a također i u bitnoj povezanosti s Novim zavjetom, spominju siromašni i pitanja socijalne pravde (vidi: Schottroff i Stegemann, 1978, 1979; Santa Ana, 1979; Hochgrebe 1982). O diskusiji i analizi današnjih klasnih strategija u ophođenju sa siromašnima i zakinutima te o njihovoj stigmatizaciji, vidi studiju čiji su autori Savage i dr. (2015: 401).

4 S Wilkinsonom i Pickettom započinje nova faza društveno-političke diskusije o socijalnoj nejednakosti te se ovdje sljedećom izjavom zauzima jasno stajalište: "U ovoj knjizi pokazuje se da je kvaliteta društvenih odnosa u društvu utemeljena na materijalnoj osnovi. Razlike u razini dohotka imaju snažan utjecaj na to kako se odnosimo jedni prema drugima. Umjesto da krivimo roditelje, religiju, vrijednosti, obrazovanje ili naš kazneni sustav, pokazat ćemo da razina nejednakosti ima presudan utjecaj na psihološki boljitak svih nas" (2010: 4). Za njemačku diskusiju egzemplarno usp. Wehlera koji ulazi u debatu kao društveni povjesničar, pritom strukturno-analitički oštro argumentirajući protiv životnoga stila, kako argumentira teoretičar individualizacije, te između ostaloga diskutira o klasnom pitanju na primjeru bračnoga tržišta i strategija sklapanja braka koje su na tom tržištu dopuštene (2013: 94). 
du" u njezinoj teoriji i praksi u pogledu priče o brizi za siromašne, kao i u divergentnim kontekstima "kršćanske ljubavi prema bližnjemu”, oduvijek bilo konstitutivno za samorazumijevanje i političku svijest, a također je, s obzirom na konceptualnu višeznačnost, zahtijevalo pojašnjavanje, te da stoga u ovome trenutku može zahtijevati posebno zanimanje. U današnjim je prilikama, međutim, središnje pitanje, koliko (dobro) utemeljena "socijalna kretanja" mogu, izvan moralnih diskursa ${ }^{5}$, sudjelovati u društvenim sukobima i borbama koje su izraz hegemonističkih diskusija o "dobrom životu” sviju (usp. Sünker 2015). ${ }^{6}$

5 To je također predmet Bourdieusove kritike Habermasa, kada argumentira da ovaj "socijalne odnose podvrgava dvostrukoj redukciji ili da ih, što dođe na isto, podvrgava dvostrukoj depolitizaciji koja dovodi do toga da se politika iznenada dovodi na teren etike. On političke odnose moći reducira na komunikacijske odnose (te na 'nenasilnu snagu argumentativnog diskursa koji bi trebao biti u stanju dovesti do sporazuma i prouzročiti konsenzus'), znači na 'dijaloške' odnose, iz kojih je praktički izdvojio odnose moći koji se ovdje pojavljuju u uljepšanom obliku" (2001: 85).

6 U ovom se kontekstu u socijalno-političkom smislu u slučaju Savezne Republike Njemačke poseban značaj pridaje neoliberalnoj Agendi 2010 (reforma socijalnog sustava iz 2003., op. prev.) te zakonskoj regulativi Hartz IV (politika novčana naknada za nezaposlene, op.prev.), političkim odlukama koje su 1. ukrale pojam reforme (vidi: Hirschman, 1993); 2. danas potpuno pogrešno prikazuju da su dovele do poboljšanja situacije na tržištu rada (smanjenja broja nezaposlenih), ali su de facto smanjile kvalitetu rada i stvorile više 'working poor' te gubitak produktivnosti; i, završno, presudno je da je za probitak na strani političkih karakternih maski u slučajevima kao što su ovi (Clinton je drugi primjer sa svojom navodnom "welfare reform") potreban lumpenproletarijat koji nakon vlastitog 'uspona' obavlja prljave poslove za kapital.
U tom smjeru refleksivnog postupanja s poimanjem "pravde" upućuje još jedna izjava Karla Marxa sadržana u njegovom pismu Friedrichu Sorgeu od 19. listopada 1877. kojim iskazuje bijes prema svojem protivniku Dühringu i njegovim sljedbenicima, te piše da je potrebno razračunati se "s čitavom bandom poluslobodnih studenata i superpametnih doktora koji socijalizmu žele dati "viši, idealni" smjer, odnosno zamijeniti materijalističku bazu (koja iziskuje ozbiljno, objektivno proučavanje ako se na njoj želi djelovati) [...] modernom mitologijom s njenim božicama pravde, slobode i bratstva" (Marx, 1973: 303). Prema tome se radi o semantici i kontekstualiziranju pojma, o njegovom historijski-konkretnom značenju u društvenim konstelacijama, o kriterijima. Moguć temelj za koncepte socijalnoga rada nalazimo kod Michaela Walzera koji argumentira:

"kritiku dominacije treba usmjeriti protiv otvorenog distributivnog načela. Niti jedno društveno dobro x ne bi trebalo biti distribuirano muškarcima i ženama koji posjeduju neko drugo dobro y samo na temelju posjedovanja y, a bez da se uzima u obzir značenje dobra x" (1983: 20). ${ }^{7}$

Obuhvatimo li i posljedice koje su rezultat klasno-analitičkog postupanja, kod Savagea nalazimo značajne rezultate za socijalni rad kroz jedan oblik argumentiranja, s pomoću kojega se izbjegavaju (ili je moguće izbjeći) ograničenja koja proizlaze iz koncentriranosti na pitanja pravednosti koja se pojavljuju na društvenoj površini, te fokus pada na ukupne društveno analitičke i društveno-političke temelje od važnosti za disciplinu. Pritom postaje jasno da se radi o

7 Vidi još priloge koji, po mom mišljenju, služe kao smjernice: Forst (1994); Ladwig (2000). 
tome da se umjesto individualizirajućih imputacija prakticira strukturalna analiza: "Kao zaključak možemo predložiti pet točaka. Prvo, dovođenje u pitanje stereotipa o onima na dnu hijerarhije društvenih klasa. Pokazali smo u knjizi kako se radi o skupini koja služi kao gromobran za stigmatizaciju i marginalizaciju. To je povezano s nestabilnošću i fragmentacijom ranijih podjela između srednje i radničke klase, s obzirom na to da veliki broj ljudi gleda na one koje vide ispod sebe kao pripadnike nemoralnih i devijantnih grupa. U tome nema ništa novo, no danas se te tendencije javljaju s posebnom zlobom. Inzistiralo se da je ovakva politike stigmatizacije duboko problematična time što dodatno šteti već dovoljno teškim životima onih socijalno najugroženijih... Možemo samo podržati istraživače poput Imogen Tyler, Tracy Schildrick, Roberta MacDonalda i Beverley Skeggs, te stručnjaka za javne politike poput John Hilla koji pokazuju da u stvarnosti životi onih na dnu nisu označeni amoralnim iskorištavanjem... već nesigurnošću... Drugo, moramo više paziti na ponašanje onih na vrhu. Ovdje je središnje dovesti u pitanje $u$ kojoj mjeri je njihov rastući ekonomski kapital opravdan" (Savage, 2015: 404; istaknuo H. S.).

Nastavak ove problematike nalazimo kod Bourdieua kao zahtjev za metodologijom i metodom te razumijevanjem, tj. u njegovoj analizi uvjeta i mogućnosti "demokratske politike":

"Ona vrsta medicine koja je prema Hipokratovim mjerilima "prava medicina", počinje prepoznavanjem nevidljivih bolesti, znači kod činjenica o kojima bolesnik ne govori, bilo zato što ih nije svjestan ili zato što zaboravlja saopćiti ih. Ovo također vrijedi i za društvenu znanost koja želi upoznati i razumjeti stvarne uzroke bolesti koja se iskazuje samo u obličju društvenih znakova koje je, bu- dući da se čine i suviše transparentnima, teško interpretirati... Želimo li dospjeti ispod površine očiglednih činjenica, na kojoj se 'doksozofi' (Platon) - tehničari mišljenja sa znanstvenim prenavljanjem hrvaju s tobožnjim istraživačima mišljenja, tada je, naravno, potrebno vratiti se sve do stvarnih gospodarskih i društvenih determinanti bezbrojnih ograničenja osobne slobode, legitimnih zahtjeva za srećom i samoostvarenjem, ograničenja koja danas ne dolaze samo od nemilosrdnih pritisaka tržišta rada i stanovanja, već također i u obliku osuda akademskog tržišta i otvorenih sankcija ili podlih ataka poslovnog života. Stoga se mora probiti štit projekcija koje su nerijetko apsurdne, a često i gnusne, pomoću kojih se nelagoda i patnja istovremeno i jednakomjerno iskazuju i zataškavaju" (1997: 825; usp. Schultheis i Schulz, 2005). ${ }^{8}$

II.

Marx je predstavio povijesno-sistematično orijentiranu analizu različitih modusa podruštvljenja, u kojoj je riječ o teoriji povijesti, a ne o filozofiji povijesti.

8 Usp. Bourdieuovu prosudbu: "Vrlo je često sama povijesno nastala iluzija o neponištivoj jedinstvenosti individue ono što nas sprječava da ono što nazivamo osobnim iskustvima čitamo kao simptome. Ta 'osobna' iskustva se naravno mogu doživjeti kao takva, pa ipak ostaju proizvod upisanosti određenih društvenih iskustava u neki društveni poredak; društvenih iskustava koja je moguće iskazati kroz opće pojmove. Prema tome nije slučajno što se banalnost izrazito ritualiziranoga diskursa u naročito teškim slučajevima svakodnevnoga života pokazuje kao jedina mogućnost da se izreče neizrecivo. Krajnje neosobno dobro izražava ono što se doživljava kao krajnje osobno samo zato što je krajnje osobno često, pa tako i ovdje, krajnje neosobno" (1997: 461; vidi također Bourdieu, 1997: 786, 793). 
Pritom su perspektivno pojašnjena posredovanja između društvenih struktura i egzistencijalnih uvjeta društvenih klasa i pojedinaca u odnosu na razvojne potencijale: "Osobni odnosi ovisnosti (isprva sasvim prirodno) prvi su društveni oblici u kojima se ljudska produktivnost razvija tek u maloj mjeri i na izoliranim točkama. Osobna neovisnost zasnovana na faktičnoj ovisnosti, drugi je veliki oblik, u kojem se tek stvara sustav opće društvene izmjene tvari, univerzalnih odnosa, mnogostranih potreba i univerzalnih bogatstava. Treći je stupanj slobodna individualnost utemeljena na univerzalnom razvoju individua i podređivanju njihove zajedničke, društvene produktivnosti kao njihovog društvenog bogatstva. Drugi stupanj stvara pretpostavke za nastanak trećega” (usp. Wallerstein, 1984).

Za našu je analizu odlučujuć prikaz drugoga stupnja, kod kojega "osobna neovisnost", dakle "sloboda" na pojavnoj razini kapitalističkog podruštvljenja korespondira $s$ dubinski strukturalnom realnošću "faktičke ovisnosti", prisili svakoga da svoju radnu sposobnost prodaje u obliku radne snage kao robe. Istovremeno je u taj stupanj do jedne određene točke, na kojoj razvoj kapitala sam sebe ograničava, smješten razvoj društva i njegovih članova, koji Marx naziva "velikim civilizirajućim utjecajem kapitala”, jer se isto u načelu može odnositi na potencijale univerzalnosti i svestranosti koje određuje razvoj kapitala. 'Problem' cjeline tada se sastoji u tome što kapitalistička nedvojbenost oblika podruštvljenja te posljedično i proizvodni proces stvaraju velike nepravde i socijalne nejednakosti. One su posljedica "privida ekvivalentne razmjene" (Marx) i klasnih strukturiranosti koje su svojstvene odnosima sila i moći. Ovdje zastupana teza, prema tome, glasi da je kod svjesne društveno-političke analize koja pitanja načina života i kvalitete života povezuje s klasno-uvjetovanim i klasno-uvjetujućim strukturnim pitanjima, apsolutno presudno riječ o tematici "demokracija i/ili kapitalizam". 9

U svjetlu s tim povezane debate o socijalnom preokretu, "reformi i revoluciji”, Steinvorth u svojoj studiji "Jednaka sloboda" donosi socijalno-teoretski utemeljen društveno-politički pristup koji je suštinski radikalno reformski orijentiran, a riječ je o konceptu ne revolucionarnoga "demokratskoga minimuma", već minimuma koji bitno uvažava ustav Savezne Republike Njemačke te koji je usmjeren prema omogućavanju onih nivoa obrazovanja i djelovanja "koji svakoga osposobljavaju za političko suodlučivanje; jer bez te sposobnosti čovjek ostaje isključen iz svih odluka koje se tiču njega samoga i koje čine okvir njegovog samoodređenja; potom i sposobnost sudjelovanja u proizvodnom procesu, unutar kojega se može izboriti za materijalne uvjete za svoju egzistenciju" (1999: 277). ${ }^{10}$

Ovo je stajalište moguće povezati $s$ makrosociološkom tezom koja se odnosi na razvoj zapadno-kapitalističkih društava o demokratizaciji kao realnom po-

9 Nisu uključeni problemi velikog formata koje ovdje nećemo detaljnije obrađivati:

a) Odnos politike i ekonomije, što se u kapitalizmu, uglavnom, predstavlja kao pitanje primata ekonomije; usp. klasično Polanyi (1978) i suprotno Sen (2000).

b) Temeljna počela kolonijalizma, imperijalizma, državnog kapitalizma, globalizacije i njihovih alternativa; usp. raznolika akcentuiranja kod Heller/Feher/Markus (1983); Duchrow (1997); Harvey (2005); McCarthy (2009).

${ }^{10}$ Ovo valja povezivati s pitanjem socijalne $\mathrm{dr}$ žave, dakle radi se o zadaći interpretacije semantike, politike te perspektive; usp. na tu temu još uvijek elementarnog Hartwicha (1977). 
kretu, a moguće je riječ o neminovnoj tendenciji tijekom zadnjih dvjesto godina:

"Njezina je posljedica da velik broj ljudi čak i u slučaju najveće moguće lojalnosti spram postojećeg poretka tijekom svojega života očekuje tri stvari: dugogodišnje obrazovanje, stalno, dobro plaćeno zaposlenje i materijalno osiguranje za starost. Ovom bi se popisu očekivanja mogao dodati krov nad glavom, a stambeno je zbrinjavanje također skupo" (Wallerstein i dr., 2014: 214; istaknuo H. S.).

U okviru dijagnoze za budućnost koja predviđa da će nadolazeća desetljeća čovječanstvu donijeti iznenađujuće šokove i silne izazove, valja naglasiti političku logiku stvaranja blagostanja, a također i to da njegovo postajanje u neoliberalizmu postaje nezgodno:

"U ovoj knjizi želimo, na osnovi našeg sociološkog poznavanja svjetske povijesti, istražiti i prodiskutirati kako će po svemu sudeći ti izazovi i mogućnosti izgledati. Ono što nas u biti uznemirava jest činjenica da je po okončanju hladnoga rata prije gotovo tri desetljaća postalo zastarjelo ili čak sablažnjivo govoriti o budućnosti svijeta, a posebno kapitalizma. Udružili smo se oko ove neobične knjige jer se nešto u daljini naslućuje, naime strukturna kriza daleko većih razmjera od one nedavne velike recesije koja bi se retrospektivno mogla pokazati predigrom jednome razdoblju koje donosi još dalekosežnije poremećaje i transformacije" (Wallerstein i dr., 2014: 7; istaknuo H. S.). ${ }^{11}$

$11 \mathrm{U}$ perspektivi Wallerstein kao alternativu vidi razvoj demokracije ili prijelaz na fašizam; usp. daljnje analize kritičke teorije o povezanosti kapitalizma i fašizma Sünker (2006).

U tom su kontekstu važne analize SAD-a i njihov mogući razvoj: vidi Davis (1986);
Vraćajući se na klasični lajtmotiv kritičke teorije, Castells na kraju svoje trilogije The Information Age imenuje temeljni problem kapitalizma koji nije moguće riješiti s pomoću 'pravedne raspodjele’: "postoji ogromni jaz između naše tehnološke razvijenosti i naše društvene nerazvijenosti" (Castells 1998: 359). I ta ga analiza dovodi do zahtjeva: "Ne treba nam samo odgovorna vlast, već odgovorno, obrazovano društvo" (ibid.: 353), potrebni su, dakle, obrazovane građanke i građanil2 koji promišljaju i koji su u društvenom smislu sposobni prosuđivati, a u političkom smislu sposobni djelovati kako bi uredili svoje društvene odnose, naročito danas s obzirom na propadanje "političke klase" i širenje oligarhijske vladavine.

Nasuprot tomu stoji 'samo', u međuvremenu generalizirana društvena realnost sa svojim rascjepima koji u međuvremenu već dosežu nivo ranograđanskih-kapitalističkih odnosa; kao što je moguće egzemplarno pronaći u Hegelovoj analizi "građanskoga društva" koji k tomu navodi pretpostavke i posljedice $\mathrm{u}$ odnosu na neprivilegirane, s obzirom na njihove načine života, opredjeljenja, stavove i vrijednosti:

"Potonuće velike mase ispod nivoa određenog egzistencijalnog minimuma koji se sam regulira kao nužan za nekog člana društva, čime dolazi do gubitka osjećaja za pravo, poštenja i časti da se opstane zahvaljujući svom djelovanju i radu, dovodi do stvaranja rulje, što pak istovremeno ima za posljedicu da se nerazmjerna bogatstva s većom lakoćom

Wallerstein (2004); Berman (2005) - pritom su i naslovi studija zanimljivi!

12 O debati o obrazovnom sustavu i stanju društva, reprodukciji socijalne nejednakosti vidi članke Sünker, Timmermann i Kolbe (1994) i Sünker (2007). 
koncentriraju u rukama manjeg broja ljudi” (Hegel, 1955: \$244).

Kada je riječ o produkciji manje "bogatih", a više "siromašnih", Hegel također upozorava na povijesno-konkretne, sustavne i postojane, kapitalu svojstvene probleme:

"Nametne li se bogatijoj klasi direktna obveza... da masu koja se približava siromaštvu održava na razini njezinog redovnog načina života, osigurao bi se životni minimum potrebitih, a da nije došao od rada, što bi bilo protivno načelima građanskoga društva te protivno osjećaju samostalnosti i časti njegovih pojedinaca; ili ako bi taj životni minimum došao posredovanjem rada (ako bi se za to pružila prilika), uvećala bi se količina proizvodnje, u čijem je izobilju te u oskudici razmjernog broja potrošača koji su sami produktivni, upravo sadržano zlo koje se na oba ova načina samo povećava. Time na vidjelo izlazi da građansko društvo i kod sve te prekomjernosti bogatstva nije dovoljno bogato, odnosno da ne posjeduje dovoljno toga, svojstvenog mu imetka, da bi se moglo boriti s prekomjernošću siromaštva i nastajanjem rulje” (\$245).

Kroz suvremenu analizu kapitalizma sjevernoamerički politički ekonomisti S. Bowles i H. Gintis na početku svoje studije pod naslovom "Democracy \& Capitalism” zaključuju sljedeće:

"Ova studija je vođena predanosti ideji progresivnom proširenju sposobnosti ljudi da upravljaju svojim osobnim životima $i$ društvenim povijestima. Ova ideja zahtjeva uspostavljanje demokratskog društvenog poretka i dokidanje glavni institucija kapitalističke ekonomije. Tako snažno suprotstavljanje 'kapitalizma' i 'demokracije', pojmova koji zajedno karakteriziraju naše društvo, može izgledati neopravdano. No, mi tvrdimo da niti jedno kapitalističko društvo danas se ne može razumno smatrati demokratskim u smislu osiguranja osobnih sloboda i društveno odgovorne upotrebe moći" (1987: 3, istaknuo H. S.). ${ }^{13}$

Time navode mjerila i kriterije pomoću kojih je istovremeno moguće protumačiti kako je Adorno - zainteresiran u duhu demokratske prakse s obzirom na katastrofalno 20. stoljeće s nacionalsocijalizmom, kao njemačkim oblikom fašizma, staljinizmom i raznim imperijalizmima i autoritarnim režimima - došao do zaključka da se demokracija nije udomaćila u tolikoj mjeri da bi je ljudi zaista spoznavali kao svoj vlastiti interes ili da bi same sebe shvaćali kao subjekte političkih procesa. Demokracija, kako se upravo sada (opet) jasno pokazuje,

"se doživljava kao jedan od više sustava, kao kad bi čovjek na karti s uzorcima imao mogućnost odabira između komunizma, demokracije, fašizma, monarhije; no ne kao nešto što je istovjetno samom narodu, izraz njegove zrelosti. Ocjenjuje ju se prema uspjehu ili neuspjehu, u čemu onda također sudjeluju pojedinačni interesi, ali ne kao jedinstvenost vlastitih interesa sa sveopćim interesom" (Adorno 1971.: 15).

Pritom je važno raspoznati da tu situaciju imamo zahvaliti jednoj okolnosti koju valja nazvati "klasnim društvom", a koja je povezana s posljedicama po refleksivnost, društvenu sposobnost prosuđivanja i sposobnost političkog dje-

13 Vidi dalje Meiksins Wood na temu historijski-konkretnog pitanja kriterija u vezi "demokracije": "Kapitalizam čini mogućom vrstu demokracije u kojoj formalna jednakost u političkim pravima ima minimalan utjecaj na socijalnu nejednakost ili odnose dominacije i eksploatacije u drugim društvenim sferama" (1995: 224; usp. Jessop, 2002). 
lovanja. U skladu s time je presudno pitanje klasne analize i njezino pozicioniranje. Na tu temu E. O. Wright bilježi:

"Analiza klase, u marksističkoj tradiciji, stoji u centru rasprava o dilemama suvremenog društva i aspiracija za egalitarnom i demokratskom budućnošću čovječanstva. Klasa je normativno nabijeni pojam, ukorijenjen u idejama opresije, eksploatacije i dominacije. Ovaj koncept je u srži emancipacijske vizije besklasnoga društva i deskriptivne teorije sukoba, institucija i društvene promjene ukorijenjenih $u$ intrinzično antagonističkim interesima. Najveća ambicija ove vrste klasne analize je povezati deskriptivnu teoriju i emancipacijsku viziju na način da pridonese političkom projektu transformacije svijeta u smjeru tih ideala. Marksistička empirijska istraživanja - etnografske studije, povijesna istraživanja ili statističke analize anketnih podataka - trebaju težiti ostvarenju ove ambicije" (1997.: 519)

U tom je kontekstu, upravo iz razloga opiranja ideologiji nazvanoj TINA (There Is No Alternative), važno da društvena kritika u ljudskoj povijesti nije ništa novo te da su se, pored već spomenutih proroka iz Staroga zavjeta, protiv vladajućih ideologija uvijek ponovno "jogunile" raznoliko uobličene hereze, kako to egzemplarno i jasno razlučuje G. Duby u svojoj analizi feudalne slike svijeta: ovaj razvoj vladajućih odnosa između 800. i 1000. već u prvoj trećini 11. stoljeća dovodi do temeljite kritike društva i do pokušaja da se odnosi zaista revolucioniraju, a time istovremeno i demokratiziraju, u svim područjima života: u obliku hereze. "Hereza je zastupala jednakost, totalnu jednakost" (Duby 1986: 198).
A to je u odnosu na svladavanje vlasti, a time i "funkcija" s pomoću kojih se vlast iskazuje, preciznije značilo:

"Uvodeći bez ograničenja žene u svoje društvo, oni su (heretici, H. S.) dokinuli prepreku koja je prvobitno postavljena u društvenom prostoru. To nije ostalo nekažnjeno: dokidanjem razlike između žena i muškaraca dopuštene su najgore klevete, što je po mom sudu bio osnovni razlog neuspjeha. Heretici su premostili još jedan jaz: budući da su odbacili privilegije svećeničkoga 'zvanja', pomiješali su clerus i populus; pozvali su sve kršćane da na jednak način poste i mole se. Budući da su s druge strane upozoravali na to da treba oprostiti sve napade, da se više ne treba osvećivati niti kažnjavati, proklamirali su beskorisnost specijalista represije, stožera $i$ vojske. I konačno, svatko je unutar sekte radio svojim rukama, nitko nije očekivao da će ga drugi hraniti, nitko se nije mučio u službi gospodara: dokinuta je linija razdvajanja izmedu radnika $i$ drugih, vlastelina, zemljišnih gospodara sa sudskim ovlastima, protektora, onih koji su imali pravo izvršavati kazne" (1986: 197; istaknuo H. S.).

U sadašnjem je vremenu ovoj perspektivi neposredno po semantici srodno subverzivno mišljenje B. Moorea na kraju njegove velike studije pod naslovom "Nepravda. Socijalni razlozi za podređenost i otpor" (Moore, 1982: 671), jer kod njega čitamo:

"Uistinu prevratnički oblik kritike počinje čim narod pita treba li se neka određena društvena funkcija uopće obnašati, ne bi li se judsko društvo moglo snaći bez kraljeva, svećenika, kapitalista ili čak revolucionarnih birokrata" (ibid.; istaknuo H. S.)

Ovo vodi konceptualizaciji jednakosti, s pomoću koje bi bilo moguće ozbiljno uzeti slobodu i individualizam te bi 
se mogla prevladati uravnilovka koja karakterizira kapitalistički konzumizam i konformizam. ${ }^{14}$ Pritom bi se moglo voditi spoznajom St. J. Goulda koji kao evolucijski istraživač formulira: "Ljudska jednakost je povijesno kontingentan faktum. Jednakost nije aksiom; ona nije niti etički princip (iako bi to jednako postupanje moglo biti) niti ne postavlja norme socijalnog djelovanja. Ona je jednostavno rezultat razvojne povijesti čovječanstva" (Gould, 1995: 154).

Temeljni značaj ideja Francuske revolucije, s njezinim porivom da donese slobodu, jednakost i solidarnost, u tom kontekstu naglašava $M$. Theunissen kada u transformativnoj perspektivi naglašava njezinu zadaću i na toj osnovi ističe sljedeće:

"Samo građansko društvo ne posjeduje normativnu moć, već ideju na kojoj ova počiva. I moglo bi biti da ta ideja transcendira građansko društvo te da bi svoj primjeren izričaj mogla pronaći tek $\mathrm{u}$ nekoj drugoj društvenoj formi” (Theunissen, 1981: 12). ${ }^{15}$

14 Kao alternativno ishodište vidi Sünker (2008): analiza priloga Henria Lefebvrea na temu svakodnevnog života i kulturne revolucije. $\mathrm{Na}$ temu Heineovog diferenciranja jednakosti i uranilovke vidi Kreutzer (1970). Za socijalnu strukturno-analitičku podlogu alternative vidi Vester i dr. (2001) koji detaljno i iznijansirano razrađuju posredovanje klasnoutemeljenih miljea, svijesti i političkih orijentacija.

15 Usp. također Theunissen (1973): "Međutim, činjenica da je kršćanstvo antičko robovlasničko društvo tjeralo u feudalno društvo, a ovo pak dalje u građansko društvo, ne govori protiv njegovog revolucionarnog potencijala, već u prilog tom potencijalu. Iz njegovih se moralnih premisa može zaključiti da bi se društveno ostvarilo tek u materijalno-demokratskom socijalizmu, otvorenom za sudjelovanje. Drugo je pitanje što bi izgledi za to njegovo svjetovno ostvarenje zbog njegovih
Da je ta druga društvena forma moguća te potrebna, to dokazuju - također još u svojoj analitičkoj skučenosti - diskursi o "socijalnoj pravdi" u socijalnoj filozofiji, društvenoj teoriji i socijalnoj politici. Smjernicom bi se, osim toga, moglo držati ono što Bourdieu definira na sljedeći način:

"Ako je točno da je teško moguće spriječiti ili čak promijeniti ekonomske i društvene mehanizme koji stoje u pozadini najgorih oblika patnje, naročito one kojima su regulirani tržište rada i školstvo, tada također vrijedi i da se svaku politiku koja u potpunosti ne iskorištava postojeće mogućnosti djelovanja, na koje je uz znanstvenu potporu moguće ukazati, koliko god te mogućnosti bile skromne, može optužiti za nepružanje pomoći osobama u nuždi” (1997: 826).

Ovo je do danas središnje mjesto kritičke teorije:

"Ako kritička teorija ima ikakvo značenje, onda je to radikalno promišljanje koje dovodi u pitanje ono što se smatra službenom verzijom povijesti i intelektualnog projekta. Benjamin je prvi krenuo s takvim pristupom, ali Max Hokrheimer mu je dao naziv kada je postao direktorom Frankfurtske škole 1930: kritička teorija stajala je u opoziciji svim intelektualnim pokretima u 20. stoljeću koji su korišteni kao sredstvo za očuvanje postojećeg društvenog poretka - logički pozitivizam, vrijednosno neutralna znanost, pozitivistička sociologija, itd. Kritička teorije je bila u otporu onome što kapitalizam čini osobama koje ek-

nesretnih alijansi i njegove klerikalne izobličenosti vjerojatno bili minimalni. No kad bismo njegovu zaboravljenost željeli okrenuti protiv njega samoga, kao kriterij istinitosti bi, umjesto dobrog principa intersubjektivnog izražaja, bilo istaknutno ono loše postojeće" (istaknuo H. S.). 
sploatira - kupujući nas jeftino s potrošačkim dobrima, tjerajući nas da zaboravimo da je drugačiji život moguć, omogućavajući nam da zaboravimo istinu da smo zarobljeni u sustavu kroz našu fetišističku predanost i rastuću ovisnost o novim navodno must-have proizvodima" (Jeffries, 2016: 21).

Nadovezujući se na Horkheimerova izlaganja o programatici Frakfurtske škole sa središnjom točkom materijalističkog preformuliranja idealističke ideje razuma kao rada na društveno stvorenoj nepravdi i patnji i na dokidanju te nepravde i patnje, te u povezanosti sa srećom sviju, ovo je stajalište riječima Marcusea, koji ga je istovremeno komentirao, glasilo:

"Kritička teorija društva je, u skladu s uvjerenjem njezinih utemeljitelja, bitno povezana s materijalizmom. To ne znači da se time kao filozofski sustav postavlja protiv drugih filozofskih sustava. Teorija društva je ekonomski, a ne filozofski sustav. Prvenstveno postoje dva momenta koji povezuju materijalizam s pravom teorijom društva: briga za sreću ljudi i uvjerenje da je tu sreću moguće doseći jedino mijenjanjem meterijalnih okolnosti postojanja" (Marcuse, 1968: 104). ${ }^{16}$

16 Vidi na tu temu socijalnofilozofsku i društvenopolitičku perspektivu Adorna: "Ostvaren identitet bio bi ponajprije pomirenje antagonističkih interesa, a ne umirenost zato što bi sama ideja svih antagonizama, time što dopušta život, dopuštala nešto poput pomirbe među ljudima, naime njihov nastavak života... S tog bi se aspekta pomoću jedne pomalo smione formulacije moglo reći da bi zapravo ostvaren identitet, dakle uklanjanje svih antagonizama, morao biti pomirenje onoga što je na osnovi svojih nepomirljivih interesa sukobljeno, da upravo ostvareni identitet ne bi bio identifikacija svega pod jednom totalnošću, jednim pojmom, jednim integralnim društvom, već bi ostvareni identi-
Ovo se, također i kod kasnog Adorna, spaja s odgovorom na pitanje o uvjetima pod kojima dolazi do mogućnosti kvalitativne društvene promjene u kasnokapitalističkim okolnostima, kroz pitanje, "za što se treba zanimati jedna takva sociologija ili znanost o društvu koju zanima ono bitno, na što se zapravo treba fokusirati. I tu bih ja sada ipak rekao: bitne su objektivne zakonitosti kretanja društva koje odlučuju o sudbini ljudi, koje su njihov usud - a baš to treba mijenjati, i koje, s druge strane, sadrže i mogućnost, potencijal da će biti drukčije, društvo prestaje biti prisilna skupina u koju je čovjek dospio tek tako" (1993: 42, istaknuo H. S.; usp. Adorno 1969: 368f., 398; Bourdieu 2004: 18). ${ }^{17}$

Da bi se toj društvenoj promjeni pridodala emancipacijska kvaliteta, ponajprije je potrebna svjesnost sviju. ${ }^{18}$ Ovo je usmjereno na analizu i kritiku onih okolnosti koje, kako kaže Bourdieu, omogućavaju stvaranje "demokratske" dokse, "u skladu s kojom su svi građani u jednakoj mjeri ovladali političkim proizvodnin instrumentima - instrumentima koji su nužni da bi se političko pitanje kao takvo prepoznalo, razumjelo te da bi se na njega odgovorilo u skladu s vlastitim političkim interesima i na temelju ukupnih mogućnosti izbora koje

tet morao biti svjesnost neidentiteta, ili možda točnije, uspostavljanje pomirenog neidentiteta, kao što to, uostalom, čini sadržaj Hölderlinove utopije u jednoj mjeri o kojoj bi nas, doduše, uobičajena interpretacija Hölderlina mogla prevariti” (Adorno, 2006: 82).

17 Tematski se ovime postavlja pitanje o konceptima solidarnosti i solidariziranja (vidi na tu temu klasičan pristup Vestera (1970), također kao alternativu građanskom egoizmu i individualizmu (usp. Euchner, 1973).

18 Riječ je o prosvjetno-teorijskom osnovnom motivu Heydorna (1979: 289, 337) koji je usmjeren protiv svih vrsta manipulativnih formiranja svijesti. 
generiraju politička načela koja tim interesima odgovaraju" (2001: 88). Stoga je nužno boriti se protiv iluzije koja se stvara "kada se svima priznaje jednako pravo na osobno mišljenje, ali se svima ne učine dostupnima sredstva da to formalno univerzalno pravo iskoriste" (ibid.: 89).

Tako bi se možda moglo postići ono što je Heine prije gotovo 180 godina formulirao kao političku zadaću obrazovanja:

\section{REFERENCE}

Adorno, Th. W. (1969) Negative Dialektik. Frankfurt am Main: Suhrkamp Verlag.

Adorno, Th. W. (1971) Was bedeutet Aufarbeitung der Vergangenheit? u: Gerd Kadelbach (ur.) Erziehung zur Mündigkeit. Vorträge und Gespräche mit Hellmut Becker 1959-1969. Frankfurt am Main: Suhrkamp Verlag, 10-28.

Adorno, Th. W. (1993) Einleitung in die Soziologie. Frankfurt am Main: Suhrkamp Verlag.

Adorno, Th. W. (2006) Zur Lehre von der Geschichte und von der Freiheit. Frankfurt am Main: Suhrkamp Verlag.

Berman, M. (2005) Finstere Zeiten für Amerika. Ende einer imperialistischen Ära. Frankfurt am Main: Suhrkamp Verlag.

Bourdieu, P. i dr. (1997) Das Elend der Welt. Zeugnisse und Diagnosen alltäglichen Leidens an der Gesellschaft. Konstanz: UVK Verlagsgesellchaft.

Bourdieu, P. (2001) Meditationen. Zur Kritik der scholastischen Vernunft. Frankfurt am Main: Suhrkamp Verlag.
"Ako uspijemo postići da velik broj ljudi shvati sadašnjost, tada narodi više neće dopustiti da ih piskarala aristokracije huškaju na mržnju i rat, ostvarit će se veliki savez naroda, sveta alijansa nacija, više $s$ međusobnim nepovjerenjem ne moramo hraniti stajaću vojsku od više stotina tisuća ubojica, njihove ćemo mačeve i konje iskoristiti za plugove, doseći ćemo mir i blagostanje i slobodu" (1972: 368, istaknuo H. S.).

A time i demokraciju!

Bourdieu, P. (2001a) Gegenfeuer 2. Für eine europäische soziale Bewegung. Konstanz: UVK Verlagsgesellchaft.

Bourdieu, P. (2004) Der Staatsadel. Konstanz: UVK Verlagsgesellchaft.

Bowles, S. i Gintis, H. (1987) Democracy \& Capitalism. Property, Community and the Contradictions of Modern Social Thought. New York: Basic Books.

Braches-Chyrek, R. i Sünker, H. (ur.) (2017) Soziale Arbeit in gesellschaftlichen Konflikten und Kämpfen. Wiesbaden: Springer.

Davis, M. (2004) Phoenix Im Sturzflug. Zur politischen Ökonomie der Vereinigten Staaten in den achtziger Jahren. Berlin: Rotbuch Verlag.

Dixon, K. (2000) Die Evangelisten des Marktes. Konstanz: UVK Verlagsgesellchaft.

Duby, G. (1986) Die drei Ordnungen. Das Weltbild des Feudalismus. Frankfurt am Main: Suhrkamp Verlag.

Duchrow, U. (1997) Alternativen zur kapitalistischen Weltwirtschaft. Biblische Erinnerung und politische Ansätze zur Überwindung einer lebensbedrohenden 
Ökonomie. Gütersloh: Matthias-Grunewald-Verlag.

Euchner, W. (1973) Egoismus und Gemeinwohl. Frankfurt am Main: Suhrkamp Verlag.

Fleischer, G. (1989) Von Menschenverkäufern, Baschankühen und Rechtsverkehrern. Die Sozialkritik des Amosbuches in historisch-kritischer, sozialgeschichtlicher und archäologischer Perspektive. Frankfurt am Main: Suhrkamp Verlag.

Forst, R. (1994) Kontexte der Gerechtigkeit. Frankfurt am Main: Suhrkamp Verlag.

Gould, St. J. (1995) Das Lächeln des Flamingos. Frankfurt am Main: Suhrkamp Verlag.

Han, B. C. 2015: Psychopolitik. Neoliberalismus und die neuen Machttechniken. Frankfurt am Main: Fisher Taschenbuch.

Harvey, D. (2005) Der neue Imperialismus. Hamburg: VSA.

Hartwich, H. (1977) Sozialstaatspostulat und Gesellschaftlicher Status quo. Opladen: Westdeutscher Verlag.

Heine, H. (1972) Werke und Briefe. Weimar: Volksverlag Weimar.

Heller, A., Feher, F. i Markus, G. (1983) Der sowjetische Weg. Bedürfnisdiktatur und entfremdeter Alltag. Hamburg: VSA.

Heydorn, H. J. (1979) Über den Widerspruch von Bildung und Herrschaft. Frankfurt am Main: Suhrkamp Verlag.

Hirschman, A. O. (1993) Die Rhetorik der Reaktion - Zwei Jahre danach. Deutsche Zeitschrift für Philosophie 41 (6): 959-978.

Hochgrebe, V. (ur.) (1982) Provokation Bergpredigt. Stuttgart: Kreuz Verlag. Jeffries, St. (2016) Grand Hotel Abyss. The Lives of the Frankfurt School. London: Verso.
Jessop, B. (2002) The Future of the Capitalist State. Cambridge: Polity.

Kreutzer, L. (1970) Heine und der Kommunismus. Göttingen: Vandenhoeck u. Ruprecht.

Ladwig, B. (2000) Gerechtigkeit und Gleichheit, PROKLA 30 (121): 585610.

Marcuse, H. (1968) Kultur und Gesellschaft I. Frankfurt am Main: Suhrkamp Verlag.

McCarthy, T. (2009) Race, Empire and the Idea of Human Development. Cambridge: Cambridge University Press.

Meiksins Wood, E. (1995) Democracy Against Capitalism. Renewing Historical Materialism. Cambridge: Cambridge University Press.

Mirowski, P. (2014) Never Let A Serious Crisis Go To Waste. How Neoliberalism Survived The Financial Meltdown. London: Verso.

Moore, B. (1982) Ungerechtigkeit. Die sozialen Ursachen von Unterordnung und Widerstand. Frankfurt am Main: Suhrkamp Verlag.

Polanyi, K. (1978) The Great Transformation. Politische und ökonomische Ursprünge von Gesellschaften und Wirtschaftssystemen. Frankfurt am Main: Suhrkamp Verlag.

Santa Ana, J. (1979) Gute Nachricht für die Armen. Die Herausforderung der Armen in der Geschichte der Kirche. Wuppertal: Jugenddienst Verlag.

Savage, M. i dr. (2015) Social Class in the 21st Century. London: Penguin.

Sayer, A. (2016) Why We Can't Afford The Rich. Bristol: Policy Press.

Schäfer, C. (2000) Privater Reichtum um den Preis öffentlicher und privater Armut? Die Verteilungsentwicklung in 1999 und in den Vorjahren. WSI-Mitteilungen 53 (11): 744-764. 
Schottroff, L. i Stegemann, W. (1978) Jesus von Nazareth. Hoffnung der Armen. Stuttgart: Urban-Tachebücher.

Schottroff, W. i Stegemann, W. (1979) Der Gott der kleinen Leute. Sozialgeschichtliche Auslegungen. München: Chr. Kaiser.

Schultheis, F. i Schulz, K. (ur.) (2005) Gesellschaft mit beschränkter Haftung. Zumutungen und Leiden im deutschen Alltag. Konstanz: UVK Verlagsgesellchaft.

Sen, A. (2000) Ökonomie für den Menschen. Wege zu Gerechtigkeit und Solidarität in der Marktwirtschaft. München: dtv Verlagsgesellschaft.

Steinvorth, U. (1999) Gleiche Freiheit. Politische Philosophie und Verteilungsgerechtigkeit. Berlin: De Gruyter.

Sünker, H. (2006) Kritische Theorie und Analyse des Nationalsozialismus. Notate zu Herbert Marcuses "Der Kampf gegen den Liberalismus in der totalitären Staatsauffassung", u: Marion Heinz i Goran Gretić (ur.) Philosophie und Zeitgeist im Nationalsozialismus. Würzburg: Königshausen u. Neumann, 67-83.

Sünker, H. (2008) Von der "Kritik des Alltagslebens" zur "Metaphilosophie". Henri Lefebvres philosophisch-politisches Vermächtnis der Kulturrevolution, u: Marcus A. Born (ur.) Existenz und Wissenschaft. Würzburg: Königshausen u. Neumann, 185-208.

Sünker, H. (2015) Gesellschaftstheorie, Gesellschaftspolitik und Soziale Arbeit, u: Rita Braches-Chyrek (ur.) Neue disziplinäre Ansätze in der Sozialen Arbeit. Opladen: Budrich, 119-135.

Sünker, H., Timmermann, D. i Kolbe, F. U. (ur.) (1994) Bildung, Gesellschaft, soziale Ungleichheit. Internationale Beiträge aus der Bildungssoziologie und Bildungstheorie. Frankfurt am Main: Suhrkamp Verlag.

Theunissen, M. (1981) Selbstverwirklichung und Allgemeinheit. Zur Kritik des gegenwärtigen Bewußtseins. Berlin: De Gruyter.

Todd, E. (1999) Die neoliberale Illusion. Über die Stagnation der entwickelten Gesellschaften. Zürich: Rotpunktverlag.

Vester, M. (1970) Solidarisierung als historischer Lernprozeß. Zukunftsperspektiven systemverändernder Praxis im neueren Kapitalismus, u: Diethard Kerbs, D. (ur.) Die hedonistische Linke. Berlin: Bilka, 143-198.

Vester, M. i dr. (2001) Soziale Milieus im gesellschaftlichen Strukturwandel. Zwischen Integration und Ausgrenzung. Frankfurt am Main: Suhrkamp Verlag.

Wallerstein, I. (1984) Der historische Kapitalismus. Berlin: Argument- Verlag.

Wallerstein, I. (2004) Absturz oder Sinkflug des Adlers? Der Niedergang der amerikanischen Macht. Hamburg: VSA.

Wallerstein, I. i dr. (2014) Stirbt der Kapitalismus? Frankfurt am Main: Suhrkamp Verlag.

Walzer, M. (1983) Spheres of Justice. A Defense of Pluralism and Equality. New York: Basic Books.

Wehler, H. U. (2013) Die Neue Umverteilung. Soziale Ungleichheit in Deutschland. München: C. H. Beck.

Wilkinson, R. i Pickett, K. (2010) The Spirit Level. Why Equality is Better for Everyone. London: Penguin.

Wright, E. O. (1997) Class Counts. Comparative studies in class analysis. Cambridge: Cambridge University Press. 


\section{Democracy, capitalism and social justice \\ Social and Political Perspectives Today}

ABSTRACT Author is discussing a problem of social justice by putting an emphasis on the complex relationship between democracy, capitalism and justice. The main idea explored in the article is that within conscious socio-political analysis that puts questions of the way of life and quality of life in its focus and relates these questions to class-based structural questions, the main dilemma is that between democracy or capitalism. Author offers an overview of contemporary debates related to this dilemma.

KEY WORDS Social justice, capitalism, democracy 